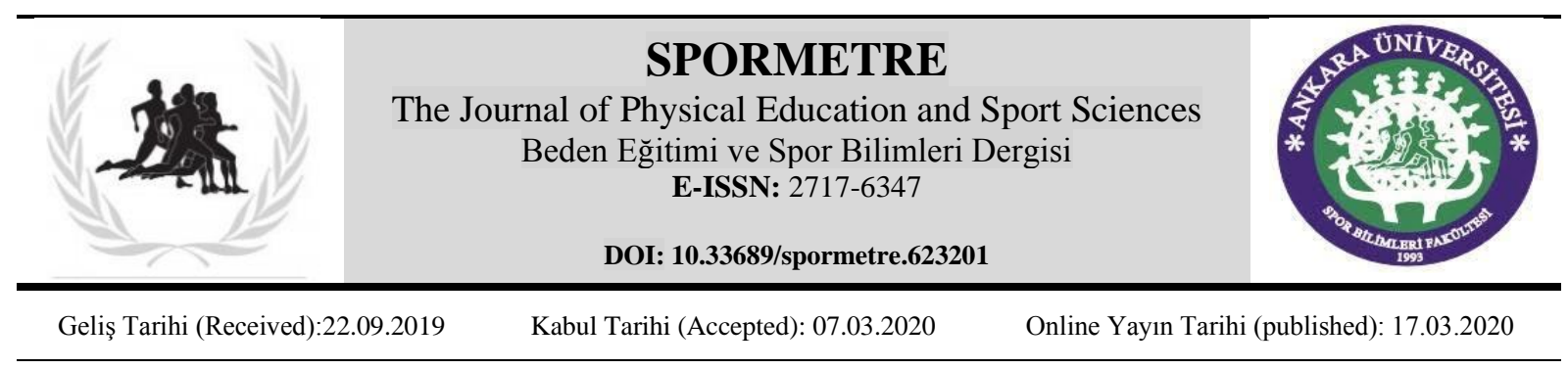

\title{
SPOR YOLUYLA PAZARLAMA KAVRAMINA ANALITİK YAKLAŞIM
}

\author{
Mustafa Zahit SERARSLAN ${ }^{\mathbb{D} *}$ \\ Mardin Artuklu Üniversitesi, Beden Eğitimi ve Spor Yüksekokulu, MARDİN
}

\begin{abstract}
Öz: Spor pazarlaması, endüstriyel ürün pazarlamasından kavram olarak da boyutları bakımından da farklılık gösterir. Gelişmekte olan bir bilim alanı olan spor pazarlaması kavramı ve boyutlarının analitik olarak ele alınması ve tartışılması spor pazarlaması yazınına ve uygulamacılarına katkılar sağlayacaktır. Spor pazarlamasının boyutlarından birisi de "spor yoluyla pazarlamadır". Bu bağlamda spor pazarlaması boyutlarından birisi olan "spor yoluyla pazarlama" kavramı ve içeriğinin ele alınıp tartışılması çalışmamızın amacıdır. Çalışmamız analitik yöntem ve tarama yöntemleri ile gerçekleş̧irilmiş̧ir. Bilindiği gibi, analitik yöntem sorgulayarak kavramsallaştırmaya dayanır. Fikirler kavramsallaşmadan insan yaşamına girememekte yani uygulamada kendine yer bulamamaktadır. Bu bağlamda bu çalışmada "spor yoluyla pazarlama" kavramı ele alınmış ve spor pazarlaması içerisindeki yeri ve boyutları analitik yöntemle belirlenmeye çalışılmışıtır. Kişi veya işletmelerin ürünlerini pazarlamada sporu kullanmaları veya spordan hem doğrudan hem de dolaylı olarak potansiyel müşterilerinin dikkatini çekmek gayesiyle vasıta biçiminde yararlanmaları neticesinde "spor yoluyla pazarlama" meydana gelir. Kişi veya işletmeler "spor yoluyla pazarlama" icra ederken belirli seçeneklerden faydalanabilirler. Bunlar; kendi içlerinde spor kulübü tesis edip dinamik bicimde sportif faaliyetler yapmak; kendi seçtiği bir spor olayı, takımı, aktivitesi yada sporcunun desteklenmesi (sponsorluğunu yapmak) ve Spor mekanı (Türk Telekom Arena), ligi (Türksel süper lig), kulübü (Vestel Manisa) isim hakkı alınması; iş bağlantılarına yardımı olabilecek bir takım sportif organizasyonların düzenlenmesini temin etmek ve bunlar gibi organizasyona dahil olmak; ürün reklamlarında sporculara yer vermek ve sporcunun kullanmış oluğu ürün veya ürün çeşitlerinin sosyal medya ortamında beğeni kazanması veya "kulaktan kulağa pazarlama tekniğinin internet ortamına uygun bir türü olarak kabul edilebilecek olan viral reklamdan yararlanmak; Lisanslama (çilek mobilya, taç...) ya da ürünleştirme eylemleri yapmak.
\end{abstract}

Anahtar kelimeler: Pazarlama, spor pazarlaması, spor yoluyla pazarlama.

\section{ANALYTICAL APPROACH TO CONCEPT OF MARKETING THROUGH SPORTS}

Abstract: Sports marketing differs from industrial product marketing in terms of concept and size. The analytical approach and discussion of the concept and dimensions of sports marketing, which is a developing science, will contribute to the literature and practitioners of sports marketing. One of the dimensions of sports marketing is "marketing through sports". In this context, the purpose of our study is to discuss the concept and content of "marketing through sports" which is one of the dimensions of sports marketing. Our study was carried out with analytical and screening methods. As is known, the analytical method is based on conceptualization by questioning. Ideas cannot enter human life without conceptualization, which means they cannot find a place for themselves in practice. In this context, "marketing through sports" concept is discussed and its place and dimensions in sports marketing are tried to be determined by the analytical method. "Marketing through sports" occurs when individuals or organizations use sports to market their goods and services, or use sports as a means of directly or indirectly reaching their target group. Individuals or organizations can make use of the following alternatives when performing "marketing through sports"; to establish sports clubs and actively engage in sports activities; to support (undertake sponsorship) any sports event, team, activity or athlete, and to obtain name rights for sports venue (Türk Telekom Arena), league (Turkish Super League), club (Vestel Manisa); to make and participate in various sports organizations to assist in business connection; to use athletes in advertising of goods and services; and benefit from viral advertisements, which can be called a type of products used by athletes that are appreciated on social media or a form of word-of-mouth marketing adapted to the internet world; to do license (Çilek furniture or Taç curtain)or productive actions.

Keywords: Marketing, sports marketing, marketing through sport. 


\section{GİRIŞ}

Kişilerin ya da örgütlerin mal ve hizmetlerini pazarlarken spordan yararlanmaları ya da sporu doğrudan ya da dolaylı olarak hedef kitlelerine ulaşmak için araç olarak kullanmaları sonucu spor yoluyla pazarlama oluşur. "Spor pazarlaması" ve "spor yoluyla pazarlama" nın sınırları belirlenmediği takdirde anlam karışıklıkları, anlama sıkıntıları ortaya çıkmaktadır. Bu bağlamda spor pazarlaması jargonunda bu ayrımın yapılmasına ihtiyaç vardır. Ancak Spor Pazarlamasının başka boyutları da bulunmaktadır. "Spor yoluyla pazarlama" dışında kalan bu boyutlar "sosyal pazarlama açısından spor pazarlanması", "hizmet pazarlaması açısından spor pazarlamas1", "sporcu pazarlaması" olarak siralanabilir (Serarslan, 1990a; Serarslan, 1990b).

Görüldüğü üzere "spor yoluyla pazarlama" spor pazarlamasının alt boyutlarından biri olarak karşımıza çıkmaktadır. Ama spor pazarlamasının başka boyutları da bulunmaktadır Şekil 1). Dolayısıyla her "spor yoluyla pazarlama" aslında bir spor pazarlaması eylemi olarak değerlendirilebilir. Ancak her "spor pazarlaması" bir "spor yoluyla pazarlama" eylemi değildir.

Spor endüstrisi dünyadaki 20 endüstriden birisidir. Kavramların iyi açıklanması ve alt başlıkların tanımlanması akademisyenlerin yapacağı spor pazarlaması çalışmalarına ve uygulamada spor endüstrisi iştirakçilerine ve paydaşlarına 1şık tutacaktır. Hal böyle olunca ticari kazançlarda artış gösterecektir (Ekmekçi, 2010).

Bu çalışmanın sonucunda "spor yoluyla pazarlama", ve "spor pazarlaması" konusunda kavram ve kafa karışıklıklarının önlenmesi beklenmektedir. Nitekim, örneğin "sponsorluk" bir "spor yoluyla pazarlama" eylemi olmasına karşılık "spor pazarlaması" yerine kullanıldığına şahit olunmaktadır. Yukarıda da ifade edildiği gibi aslında "sponsorluk", "spor pazarlaması" eyleminin altında yer alır, ancak bu eyleme "spor yoluyla pazarlama" denilmesi kavramın kafalarda daha netleşmesine vesile olacaktır. Türkiye'de TMOK tarafindan 8-9 Nisan 1991'de İstanbul Tarabya Otelde düzenlenen (TMOK, 1991) ve içeriği tamamen sponsorluk olan bir seminerin, "spor pazarlaması semineri" ya da konferansı olarak spor pazarlaması literatürüne girmesi, bunun en güzel örneğidir. Ayrıca bu konferans Türkiye'de spor pazarlaması konusundaki ilk bilimsel çalışma olarak da zaman zaman spor pazarlaması literatüründe yer almaktadır. Burada iki açıdan hata bulunmaktadır. Birincisi bu konferansın içeriği incelendiğinde bir "sponsorluk" konferansı olduğu görülecektir. Çalışmamızın devamında görüleceği gibi "sponsorluk", "spor yoluyla pazarlama"nın sadece bir boyutu olan eylemlere ilişkindir. Başka bir ifade ile "spor yoluyla pazarlama"nın içerisinde olmasına rağmen, bu kavramı tamamen kapsamamaktadır. Tam olarak "spor pazarlaması" konferansı da değildir. Çünkü "spor pazarlaması"nın diğer boyutlarını içermiyor ve kavramın eksik kaldığı gözlemleniyor. İkincisi Türkiye'de ilk bilimsel anlamda spor pazarlaması çalışması Serarslan tarafindan 1990'da yapılan ve Hacettepe Üniversitesi 1. Ulusal Spor Sempozyumu'nda sunulan ve bildiri kitabının 217-224. sayfaları arasında yer alan "Spor Pazarlaması ve Boyutları" adlı çalışmadır (Serarslan, 1990b). 


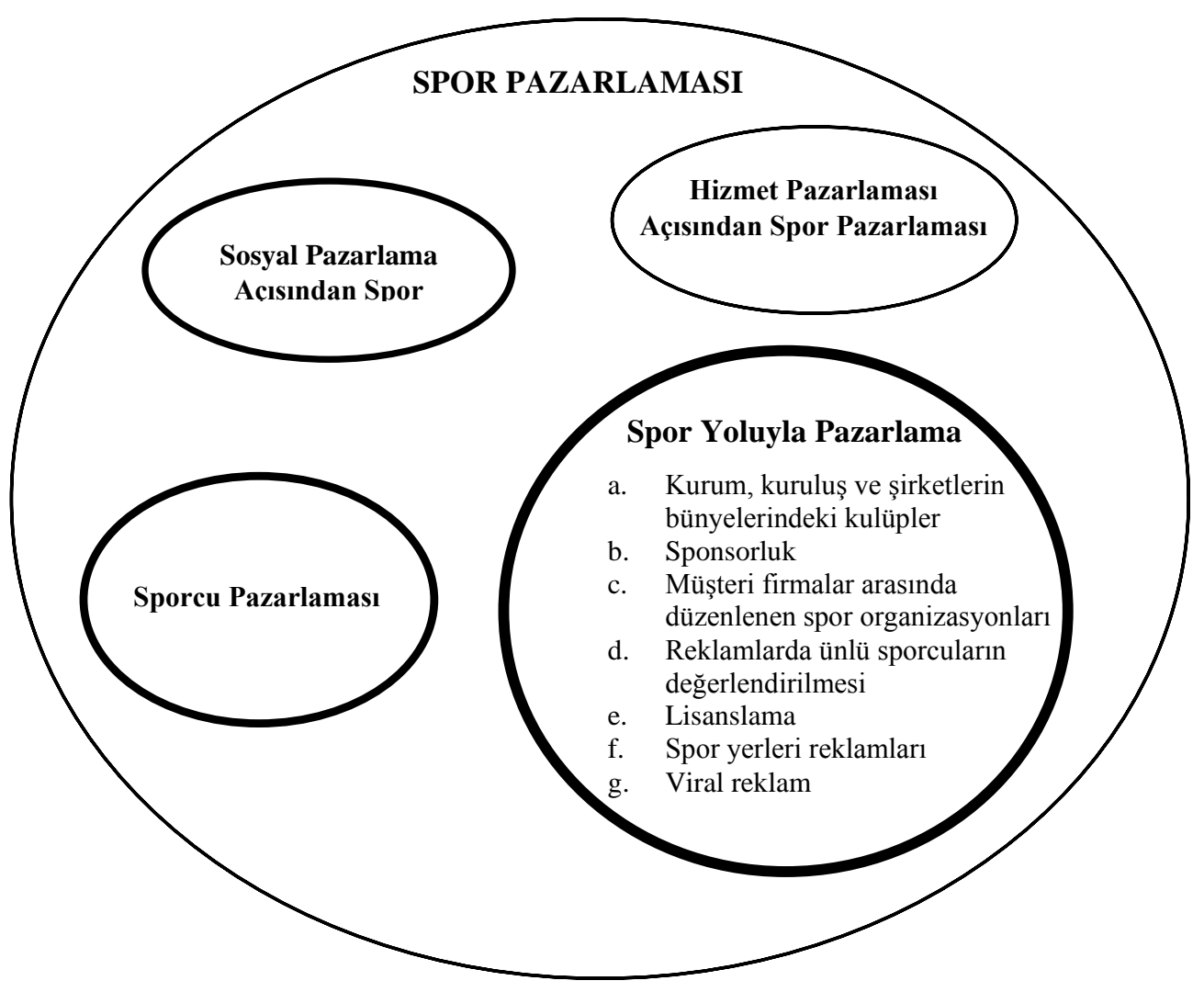

Şekil 1: Spor Yoluyla Pazarlamanın Spor Pazarlaması İçindeki Yeri.

Serarslan aynı yıl "Spor Pazarlaması: Sporun Topluma Yaygınlaştırılmasında Pazarlama Tekniklerinden Yaralanma" adlı doktora tez çalışmasını tamamlamıştır (Serarslan, 1990a). Serarslan'ın yine 1990'da yayımlanan bir diğer çalışması da "Spor mantalitesinin geliştirilmesinde pazarlama tekniklerinden yararlanma", adlı çalışmadır (Serarslan, 1990c). Bu çalışmaların sonrasında gerçekleşen sponsorluk konferansının bazı kaynaklarda, spor pazarlaması alanında ilk çalışma olarak yer alması önemli bir eksiklik olarak karşımıza çıkmaktadır. Bu bağlamda bu çalışmanın amacı spor pazarlamasının boyutlarından sadece birisi olan spor yoluyla pazarlama kavramını ve bu kavramın boyutları ve içeriğinin ne olabileceğini analitik yöntemle tartışmaktır.

\section{YÖNTEM}

$\mathrm{Bu}$ çalışma analitik yöntemle gerçekleştirilmiştir. Bilindiği gibi genç bilim alanlarında kavram kargaşaları yaşanmaktadır. Bu kargaşa, kavramlara analitik açıdan bakmamayla ilgilidir. İnsan zihninin durulaşması ve netleşmesi için kavramların sadeleştirilmesi ve analiz edilmesi gerekir. $\mathrm{Bu}$ zihinsel işlemler yapılmadan doğru tanımlar, nesnel açıklamalar yapılamaz. Bunlar olmayınca da birbirimizi doğru anlayamayız, bir kör dövüşü sürüp gider. Analitik düşünce, olgusal, somut düşünce şekli olduğu için verimli diyalogların, tartışmaların ve sonuçta uzlaşmanın zeminini oluşturmaktadır (Yaka, 2011). Analitik yöntem sorgulamaya dayanır. Bu sorgulama sonucunda da kavramsallaştırma mümkün olabilmektedir. Sağlıklı analiz olmadan sağlıklı sentezler de ortaya çıkamamaktadır. Fikirler kavramsallaşmadan insan yaşamına girememekte yani uygulamada kendine yer bulamamaktadır (Turgut, 1984). Bu bağlamda bu çalışmada spor yoluyla pazarlama kavramı ele alınmış ve spor pazarlaması içerisindeki yeri analitik yöntemle belirlenmeye çalışılmıştır. 
Aynı zamanda yapılan bu çalışmada tarama yöntemi de kullanılmıştır. Tarama yöntemi geçmişte var olan bir durumu olduğu gibi tespit ederek günümüze nasıl yansıdığını ortaya koyar (Karasar, 2015).

\section{Spor Yoluyla Pazarlama}

Mullin ve arkadaşlarına (2000) göre spor pazarlaması iki ana konuyu kapsamaktadır. $\mathrm{Bu}$ konulardan ilki spor hizmetlerinin ve ürününün doğrudan spor tüketicilerine pazarlanmasıdır. Süper Lig, Türkiye Kupası, bir maç, bir turnuva, bir rekreatif etkinlik v.b. faaliyetler örnek verilebilir. Diğeri ise endüstriyel ürünlerin ya da hizmetlerin pazarlanmasında sporun tanıtım aracı olarak kullanılmasıdır. Bu ikinci konu spor yoluyla pazarlama olarak ifade edilebilir. Daha önce ifade edildiği gibi Serarslan da (1990a; 1990b) çalışmalarında spor pazarlamasını dört boyutta ele almıştır. Bu boyutlardan üçü "sosyal pazarlama açısından spor pazarlanması", "hizmet pazarlaması açısından spor pazarlaması", "sporcu pazarlaması" iken, dördüncü boyut "spor yoluyla pazarlama"dır.

İnsanla bağlantı kurmanın en kolay yolu spordur, spor faaliyetleridir, spor imajıdır, global hale gelen ve bilgi çağındaki dünyamızda işletmelerin pazarlamada araç biçiminde kullandığı ve hedef kitlesiyle haberleşebildiği olgudur. Doğası gereği ürün üreten işletmelerin, yazılı, görsel ve işitsel hizmet üreten işletmelerin yatırımı sayesinde spor beraber gelişme göstermiş ve spor endüstrisi kavramı 21. yüzyılda mühim bir güç sahibi olmuştur. Değişik özelliklerdeki insanları ve grubu aynı yere getirin spor kavramının, reklam sektöründe daha uzun zaman ve gittikçe artan bir süratle pazarlama stratejisinde yer bulabileceği söylenebilir (Yıldız ve ark. 2007).

Spor her zaman kalabalık kitlenin alakasını uyandıran olgu olmuştur. Kitlenin müşteri ve potansiyel müşterilerden meydana geldiği düşünüldüğünde, spor vasitasıyla tutundurma faaliyetinin önemli olduğu açıkça anlaşılabilir. Bu nedenle hem az harcama yapıp hem de daha fazla müşteriye ulaşmayı düşünen işletme ya da işletme topluluğu, spordan tutundurma amaçlı olarak faydalanmaktadır. Bu durumun nedeni ise; sporda öteki eğlence tiplerinde bulunmayan iki özelliktir. Birincisi, medyada özel bir yer sahibi olması, ikincisi ise; doğası gereği sonucunun her zaman sürprize açık olmasıdır. (Moore, 1985).

Bugünlerde birçok spor branşı, çeşitli işletmelerin ürünlerinin tanıtımında kullanılmaktadırlar. Fakat, sporu ürün tutundurması gayesiyle kullanmakta olan firmaların nihai hedefinde hem ürünlerinin hem de işletmelerinin de reklamını sağlayarak, müşterilerde kalıcı bir şekilde imajlarını yerleştirme çalışması yer almaktadır. (Serarslan, 1990a).

İşletmeler spor yolu ile pazarlama faaliyetlerinde aşağıdaki seçeneklerden birisinden, bir ikisinden ya da yedisinden birden faydalanabilmektedirler:

- $\quad$ Kurum, Kuruluş ve Özel Şirketlerin Bünyelerindeki Kulüpler

- $\quad$ Sponsorluk

- $\quad$ Müşteri firmalar arasında düzenlenen spor organizasyonları

- $\quad$ Reklamlarda ünlü sporcuların değerlendirilmesi

- Lisanslama

- $\quad$ Spor yerleri reklamları

- Viral reklam,

Şimdi kısaca bu alternatifleri açıklayalım: 


\section{a) Kurum, kuruluş ve özel şirketlerin bünyelerindeki kulüpler}

2908 sayılı Dernekler Kanunu'na göre hazırlanan Gençlik ve Spor Kulüpleri Yönetmeliği’nde dört tip kulüpten söz edilmektedir. Bunlar sırasıyla, kurum kulüpleri, spor kulüpleri, gençlik kulüpleri, gençlik ve spor kulüpleridir (Gençlik ve Spor Kulüpleri Yönetmeliği m. 4). Ancak 23/11/2004 tarih ve 25649 Sayılı resmî gazetede yayınlanarak yürürlüğe giren 5253 sayılı yeni Dernekler Kanunu'nda kurum kulüplerinden söz edilmemektedir. Kurum kulüpleri spor kulüpleri içerisinde değerlendirilmektedir. 5253 sayılı Kanun'un 14. Maddesinde yer verilen bu kulüpler "spor faaliyetine yönelik olanlar spor kulübü, boş zamanları değerlendirme faaliyetine yönelik olanlar gençlik kulübü ve her iki faaliyeti birlikte amaçlayanlar gençlik ve spor kulübü” adıyla yer almaktadır. Bu bizce de isabetlidir.

Nitekim 2908 sayılı Dernekler Kanunu'na göre hazırlanan Gençlik ve Spor Kulüpleri Yönetmeliği'nde kurum kulüpleri "kamu kurum ve kuruluşlarında, yüksek öğretim kurumlarında ve özel kuruluşlarda kendi mensupları tarafından, bu kurum ve kuruluşların bünyelerinde kurularak kayıt ve tescilini yaptıran derneklerdir" şeklinde tanımlanmıştır. Kurum kulüpleri o kurumdaki çalışanların spor ihtiyaçlarını ve spor tesislerini sağlamakla mükelleftir. Bu mükellefiyet 3530 ve 3289 sayılı yasalarla getirilmiştir. Ancak kurum kulüplerinde, bu mükellefiyetlerini yerine getirirken gerçek amaçlarından sapmalar olduğu bir gerçektir. Nitekim kurum kulüpleri sosyal alaka merkezi haline gelmiş branşlara öncelik ve ağırlık vermektedirler (Serarslan, 1989).

Bunun sebebi kurumlar bünyelerinde kurdukları "kurum kulüplerindeki spor faaliyetleri ile bir taraftan spora hizmet ederken, diğer yandan mal ve hizmetlerinin reklamını yapmaktadırlar. $\mathrm{Bu}$ durum dünyanın her yerinde olduğu gibi, ülkemizde de gözlemlenebilir. Firmalar "kurum kulüpleri" ile yaptıkları spor faaliyetlerine daha çok yer vermektedirler. Serbest zamanlarını değerlendirmek amacıyla spora katılan çalışan sayısı bir hayli düşüktür. Kurum kulüpleri ellerindeki finansal kaynaklarını kurumun personeline spor imkanı sağlamak için harcamak yerine, daha ziyade elit sporcu yetiştirmek ya da transfer etmek için harcama eğilimindedirler. Giderek kurum kulüplerinin bünyelerinde gizli profesyonellik yerleşmektedir. Çünkü lisanslı sporcuların çok düşük bir oranı kurumda istihdam edilen mavi ve beyaz yakalılar arasındandır. Çok fazla transfer harcamaları yapılabilmektedir. Yabancı uyruklu sporculara da kurun kulüpleri kapılarını açmıştır. Firmalar bu suretle de kitle haberleşme araçlarında isimlerinden daha fazla söz ettirmek suretiyle firma imajı oluşturmak konusunda büyük bir firsatı elde etmiş olmaktadırlar (Serarslan, 1989). Bu bağlamda kurum kulüpleri 2908 sayılı Dernekler Kanunu'na göre hazırlanan Gençlik ve Spor Kulüpleri Yönetmeliği’ndeki belirtilen amacından uzaklaşmışlardır. Dolayısı ile 5253 sayılı yeni Dernekler Kanunu’nda kurum kulüplerinden söz edilmemesi isabetlidir.

Artık kurum, kuruluş ve özel şirketlerin bünyesinde kurularak Teşkilatça tescil edilen kulüplerin varlığından söz edilebilir. Böylece kurum, kuruluş ve özel şirketlerin ürünleri, hizmetleri ya da isimlerinin tutundurulması amacı ön plana çıkmıștır. Dolası ile kurum, kuruluş ve özel şirketlerin bünyelerindeki kulüpler spor yoluyla pazarlama seçenekleri arasında önemli bir yer tutmaktadir.

\section{b) Sponsorluk}

Spordan, bir tutundurma aracı olarak faydalanmanın ikinci yolu, destekleme (Sponsor)'dir. Howell Report'a göre sponsor ilişki veya sporda destekleme, "bir spora, bir spor olayına, organizasyona veya bir sporcuya karşılıklı fayda gözetilerek dişardan bir kurum veya kişi tarafından finansal destek sağlanması” şeklinde gerçekleşmektedir. Sponsorluk faaliyetlerinde 
sporun tercih edilmesi, futbol başta olmak üzere birçok spor faaliyetinin dünyanın her yerinde ortak bir dil ve kültür olarak kabul edilmesinden kaynaklanmaktadır (Akkaya, 2016).

Birçok uluslararası destekleyicinin katıldığı bir araştırmada, desteklemenin amaçları; dikkati arttırma, firmanın, malın veya hizmetin imajını iyileştirme ve yarışçılara yardım etme olarak tespit edilmiştir. Bunların ilk ikisi ön amaç, üçüncüsü ise geri planda kalan amaçtır (Otker, Hays, 1987). Nitekim bir araştırmada Türk Hava Yolları'nın Türkiye Basketbol Federasyonu'na yaptığı spor sponsorluğunu pazarlamada sporun kullanılması amaciyla yaptığı ve spor sponsorluğunun spor yoluyla pazarlama ve iletişim faaliyetleri açısından beklenen etkiyi sağladığı sonucuna varılmıştır. Türkiye Basketbol Federasyonu açısından ise Türk Hava Yolları ile yapılan sponsorluğun karşılıklı fayda sağlamak amacıyla yapıldığı ve iletişim faaliyetleri açısından beklenen etkiyi sağladığı sonucuna ulaşılmıştır (Tekin ve Eskicioğlu, 2015).

Destekleme, uygulamada firmaların bir sporcuyu desteklemesi ve bir spor organizasyonunu desteklemesi şeklinde gerçekleşmektedir. Birinci destekleme türünde, firma belli bir spor branşındaki sporcuya parasal destek sağlamak üzere harcama yapar. Bunu bir sporcu yerine, bir takım da olması mümkündür. Spor malzemeleri imal eden işletme, dünyada tanınan bir sporcuya hem malzeme hem de para desteği sağlamış olması ya da araba yarışlarının bir etabının tamamının, destekleniyor olması bu kavrama örnek olabilir. İkinci tür destekleme ise, firmaların kendilerinin düzenledikleri bir organizasyon olmayıp, daha çok kendileri dışında gerçekleşen organizasyonlara parasal katkılarda bulunmak şeklinde gerçekleşir. Dünya Futbol Şampiyonaları, Olimpiyatlar da birden çok destekleyen işletme (sponsor) yer alabilir. Spor yeri (Türk Telekom Arena), lig (Turkcell süper lig), kulüp (Vestel Manisa) isim haklarının satın alınması da bir sponsorluk türü olarak da ele alınabilir.

İşletmeler yukarda açıklanan yöntemlerle hem direkt hem de dolaylı biçimde reklam yapma amacı taşımaktadırlar. Böylece, sporcuların kıyafetlerini, kullandıkları malzemeleri vb. temin eden herhangi bir spor malzemesi imalatçısı işletmenin, bu ürünleri, sadece tribündeki seyirciler tarafindan değil, aynı zamanda televizyon izleyicilerince de görülmüş olur. Benzer biçimde, araba yarışları seyircileri de hem çıplak gözle hem de ekranlardan, fişletmenin ya da mal veya hizmetin rengini, logoyu yarış esnasında otomobilde yarış boyunca devamlı görmüş olurlar. Böylelikle reklam gideri olmaksızın, işletme ürün tanıtımı yapar.

\section{c) Müşteri firmalar arasında düzenlenen spor organizasyonları}

Firmaların iş bağlantılarını sağlayacak ortamların hazırlanmasında, spor organizasyonlarından faydalanmak ya da spor yoluyla pazarlamada başvurulan yöntemlerden birisidir. Özellikle Amerika Birleşik Devletleri'nde ilk örneklerine rastlanan bu uygulama, sporcu pazarlaması başlığı altında sözü edilen menajerlik sirkeleri tarafından muhatap firmalar arasında organize edilmektedir (McCormack, 2014). İş bağlantısı kurmak isteyen firmaların üst düzey yöneticilerini bir araya getirmek suretiyle gerçekleştirilen bu spor organizasyonları ile yöneticiler doğrudan ilişki kurma fırsatı bulmaktadırlar. Örneğin, Uluslararası Menajerlik Grubu, "Time" dergisi için yıllık kayak ve "Newsweek" için de yıllık golf gezileri düzenlemekte, bu dergilerin yöneticisi ve başkanları ile önde gelen reklam elemanları ağırlanmaktadır. Bu suretle, dergilerin en üst düzeydeki kişileri reklamcılarla işlerini doğal anlamın çok güzel olduğu bir ortamda konuşmak firsatı bulmaktadırlar. Bu durum ayrıca, reklamla ilgili bir terslik olursa, dergilerin en üst düzeydeki kişiler ile doğrudan ilişki kurmalarını da sağlamaktadır. Ancak böyle bir bağlantının kurulabilmesi için muhatap işletmelerin üst kademe yöneticilerinin ortak ilgi duydukları spor branşlarının bulunması, en azından aktif olarak spor yapıyor olmaları veya spor yapma potansiyeline bulunmaları gerekir. 


\section{d) Reklamlarda ünlü sporcuların değerlendirilmesi}

İşletmelerin ürünlerinin reklam kampanyasında ünlü sporcu olgusundan yaralanmaları, spor veya sporcu ile pazarlamayı bir araya getiren diğer bir seçenek biçiminde karşımıza çıkmaktadır. Ayrıca sporcuların kullandığı bir ürünün sosyal medyada beğeni alması ya da "kulaktan kulağa pazarlama"nın internet dünyasına uyarlanmış bir türü denilebilecek viral reklamları da bu başlık altında değerlendirmek mümkün olabilir. Ancak son yıllarda viral reklamın öneminin ve kullanıldığı alanların artması sebebiyle ayrı başlık altında ele alınacaktır. Yapılan araştırmalarda, ünlü kişilerin kullanıldığı reklamların, kullanılmayanlara oranla daha başarılı olduğu konusunda izlenimler elde edilmiştir (Freidon, 1984). Bu durumun farkında olan firmalar ve reklam ajansları mal veya hizmetlerinin reklamlarında, sporcu dışındaki ünlülerden faydalandıkları gibi sporculardan da faydalanmaktadırlar. Bu alanda sporculardan yararlanmak bir süredir $\mathrm{ABD}$ ve dünyada modadır. Bilhassa genç erkeklerin ünlü sporcuları rol model alma trendinin bu ilginin beklenen bir sonucu olduğu görülebilir. Reklam sektörü, ün kazanmış sporcuları meta olarak üretim sürecine yerleştirip, genç ve ünlü sporcu arasında oluşmuş olan bu kuvvetli iletişimden yararlanmaktadır (Stone, Joseph, Jones, (2003). Çeşitli spor branşlarında başarı kazanmış sporcunun hem ulusal hem de uluslararası bilinirliği ve ona beslenen güveni, spor ile ne doğrudan ne de dolaylı bir biçimde ilgili olsun veya olmasın çoğu işletme ürün pazarlanması için kullanıldığı görülmektedir. Ulusların büyük kısmının alakayla seyir ve takibin de bulunan spor olayı, reklam sektörünce reklamın al benisine ve ürünlerine yönelik ilgiyi yükseltecek bir faktör olarak görülmektedir. Bu durumun yanı sıra reklamda sadece sporla ilgili bireyler (sporcu, hakem, yönetici) değil aynı zamanda sporun oluşturduğu imaj, tek tek veya birlikte reklamda bulunabilmektedir (Y1ldız ve ark. 2007). Bu reklamlara, Türkiye Milli Futbol Takımı'nın Coca Cola; İlhan Mansız'ın Evy Lady; Alex De Souza'nın Finansbank; Süreyya Ayhan'ın Vestel; Sabri Sarığlu, Volkan Demirel ve İbrahim Toraman'ın Filli Boya reklamları örnek teşkil eder. Hatta dünyaca ünlü bir futbolcu olan Ronaldinho, Nike, Pepsi ve Trident Fresh olmak üzere aynı zamanda üç farklı reklam filminde oynamaktadır (Bir, 2006). Bir sporcunun çok değişik reklamlarda yer bulması sporun pazarlamadaki önemini ortaya çıkarmaktadır (Sunay ve Balc1, 2003; Zeki, 1998). Nitekim ülkemizde yapılan bir çalışmada, TV reklamlarında içinde spor imajına yer veren reklam oranları \%16 düzeyindeyken, çalışmaya katılan bireylerin beğenmiş oldukları, onları etkileyen reklam içinde bu düzey \%49,6 olarak tespit edilmiştir (Yıldız ve ark. 2007). "Bir zamanlar, spor ile pazarlama, bir sporcunun bir ürünü kamera önünde tutmasıyla eş anlamlıydı. Bugün sporcular ve onları temsil eden menajerler veya menajerlik şirketleri, yeni stratejilerle yeni kazançlar elde ediyorlar" (Moore, 1985). Bu kazançtan faydalanan yalnız sporcu veya onları temsil eden menajerlik şirketleri değil, mal ve hizmetlerinin reklamında sporcuları kullanan firmalar da satışlarını ve bağlı olarak da kârlarını arttırmak suretiyle paylarını alıyorlar (Serarslan, 1990a). Nitekim, Türkiye'de genelde ünlü futbolcuların özelde Arda Turan'ın oynadığı reklamların tüketicileri olumlu etkilediği tespit edilmiştir. Reklamlarda ünlü futbolcu kullanımının yaş ve cinsiyet açısından tüketici davranışlarında farklılaşmaya sebep olmazken, eğitim ve gelir düzeylerindeki farklılıkların tutumları değiştirdiği belirlenmiştir (Tosun, Dündar, 2019). Reklamlarda ünlü sporcu ya da diğer ünlülerin kullanımı stratejisi reklamın hatırlanmasını kolaylaştırmakta ve ürünün akılda kalıcılığını arttırmaktadır. (Sezgin ve Yılmaz, 2019)

\section{e) Lisanslama}

Lisans, dünyaca tanınmış markaların, futbol kulüplerinin, sinema ve çizgi film karakterlerinin veya dijital oyuncuların haklarının belli bir süreyle farklı bir ürün kategorisi veya bir hizmet için kullanılmasıdır. Lisans anlaşmaları gereği kulüpler diğer örgütlere, telif, tasarım, pazarlama teknikleri, marka gibi konularda tüm haklarını kendilerininmiş gibi kullandırma yetkisi verebilirler. Kulüp lisansını elinde bulunduran örgütler, kendi ürünlerine lisansını aldığı kulübün logosunu, markasını uygulayabilmektedirler. Çilek mobilya ve taç gibi bazı ürünlerde 
olduğu gibi kendi mağazalarının iç mimarisini planlamasını ve tasarımını lisansını aldığı kulüplerin marka ve renklerine göre düzenleyebilmektedirler (Ülgen ve Mirze, 2004).

Lisans kullanımı, ürünleri hedef kitle için daha çekici, prestijli, popüler ve heyecan verici kılar. Aynı zamanda iletişim kampanyaları için gündemi yakalayan içerikler sağlar. Tweety'li yastık, Bugs Bunny desenli diş fırçası, Batman oyuncak figürleri, Galatasaray renkleri ve logolu yatak örtüsü vs. lisans kullanımı için bazı örneklerdir. Lisanslamanın 172 milyar dolarlık bir hacme sahip olduğu bilinmektedir. (Lisans A.Ş)

Lisanslama başta tekstil olmak üzere, oyuncaktan GSM operatörlerine kadar uzanan geniş yelpazede kullanılmaktadır.

Spor lisansı kullanan örgütler rakiplerine karşı önemli bir stratejik avantaj elde ederler. Spor lisans1, kulüplerin ya da liglerin logolarının, renklerinin ya da sporcuların görsellerinin lisanslanması şeklinde gerçekleşebilir.

Lisanslama, ilgili spor örgütü ile bir bağlantısı olmayan herhangi bir örgüt olabileceği gibi, spor örgütleri lisanslı ürünler sunan ürünleştirme şirketleri kurabilir ya da doğrudan kendi bünyesinde bu ürünlerin satışını yapabilir. Bu bağlamda lisanslama, spor örgütünden bağımsız ya da spor örgütünün bünyesinde olmak üzere iki şekilde ortaya çıkar. Hangi şekilde olursa olsun. Bu ürünlerin satış ya da pazarlaması spor pazarlaması değil spor yoluyla pazarlama olarak değerlendirmek bize göre daha doğru olacaktır. Çünkü spor bir hizmet, lisanslı ürünler ise bir somut üründür. Ürün ve hizmet pazarlamasının farklı dinamikleri olması sebebiyle akademik çalışmalarda ve uygulamada bu yaklaşımın esas alınması işleri kolaylaştıracaktır. Öbür türlü ürün ve hizmet pazarlaması birlikte kullanılacak ve içiçe geçecektir. $\mathrm{Bu}$ da bazı hatalara ve karışıklıklara yol açabilir.

Büyük ve daha çok marka olmuş spor örgütleri ya da kulüp lisansını taşıyan ürün satışı olan mağaza açmışlardır. Yurdumuzda Anadolu kulüpleri de Kulüpler Birliği bünyesinde 'Stadium` mağaza zincirleri oluşturarak bu alan içinde olmak için çaba göstermektedirler. Oluşan bu sektörde üretilmiş ve satışa sunulan lisansa sahip ürünlerin çeşitleri kıyafet (formalar, eşofmanlar, montlar, çoraplar, atkılar, kravatlar...), aksesuarlar, ev tekstilleri, çantalar, özel koleksiyon, parfümler, çocuk eşyası vs. gibi çeşitlenmişlerdir. $\mathrm{Bu}$ ürünlere yeni ürünler eklenebilir. Bununla birlikte Manchester United logolu cafe, restorant, otel, tv ve radyo istasyonları vs çeşitlilik olarak görülmektedir. (Serarslan, 2009).

Lisanslı ürün satın alımında tüketici davranışları farklılık göstermektedir. Spor yoluyla pazarlama yapmayı tercih eden örgütlerin bu durumu göz önünde bulundurmaları başarılarını arttıracaktır. Örneğin Fenerbahça, Galatasaray, Beşiktaş ve Trabzonspor taraftarlarının satınalma davranışlarına ilişkin yapılan bir araştırmanın bulguları ilginç sonuçlar ortaya koymuştur. "Fenerbahçe taraftarlarının çocuklar için özel olarak üretilen lisanslı ürünleri satın aldıkları, Beşiktaş taraftarlarının ulaşımı kolay ve büyük mağazalar içerisinde bulunan lisanslı ürün satılan mağazalardan takımlarının lisanslı ürünlerini satın aldıkları, Galatasaray taraftarlarının lisanslı ürün satılan mağazalarda çalışan personellerin davranışlarından memnun kaldıkları için lisanslı ürün satın aldıkları ve Trabzonspor taraftarlarının çocuklarının büyüdükleri zaman başka bir takım taraftarı olmamaları için takımın lisanslı ürünlerini satın aldıkları tespit edilmiştir." (Aytaç, Yenel, 2012). 


\section{f) Spor yerleri reklamları}

Spor saha salon ve alanlarına alınan reklamlar spor örgütleri ve kamu için önemli bir gelir kaynağı oluştururken reklam verenler için de spor yoluyla pazarlama kanalı olarak karşımıza çıkmaktadır. Ülkemizde spor yerlerine alınacak reklamların şartları ayrıntılı olarak 9 Aralık 2005 tarihli ve 26018 sayılı Resmî Gazete'de yayımlanan "Gençlik ve Spor Genel Müdürlüğü İşletme Yönetmeliği” m.38-48 içerisinde yer almaktadır. Bu bağlamda reklam veren örgütte, reklamı alan spor saha ya da tesisi de bu yönetmelikteki kurallar dahilinde hareket ederler.

Spor yerleri planlamasında ve mimarisinde artık reklam alanlarının da hesaba katıldığını hatta önemli bir unsur olduğunu görmekteyiz. Bunu en güzel örneğini Fenerbahçe Uluslararası Spor Kompleksi Ülker Sports Arena'da görmek mümkündür. Nitekim Arena'nın iç mekan reklam alanları Türkiye'de "ilk" olma özelliğine sahiptir. Tribünleri dolaşan 360 derece led ekran, ağırlığı 28 tonu bulan ve Avrupa'nın en büyüğü olma özelliğini taşıyan skorbordu ile üst düzey reklam ortamı sağlamaktadır.

Bir reklam şirketinin WEB sayfasında (http://www.atareklam.com.tr/) 2019-2020 sezonunda spor yoluyla pazarlama seçenekleri arasında "spor yerleri raklamları" nı tercih edecekler için stadyumlarlardaki reklam yer ve alanları şöyle sıralanmaktadır:

"Led Pano: Saha kenarında yer alan animasyonlu ve 1şıklı reklam alanlarıdır. Bu alanlardaki reklamlar maç boyunca belirli aralıklarla değişmektedir.

Sabit Pano: Saha kenarında sabit reklam alanıdır. Stadyumun uygunluğuna bağlı olarak led panonun yanında ya da arkasnda yer almaktadır.

Korner Köşesi Sabit Pano: Korner atışları sırasında kameraların yakınlaşması sebebiyle görünürlüğü yüksek bir reklam alanıdır.

Kale İçi Sabit Pano: Canlı yayında ceza sahasında gelişen pozisyonlarda kameraların yakın çekimi nedeniyle görünürlüğü artan bir reklam alanıdır.

Protokol Önü Sabit Pano: Yedek kulübelerinin yanında, tüm stadyum seyircilerinin ve kameraların çekim alanında etkili bir reklam yeridir.

Maç öncesi / Devre Arası Led Pano: Maç başlayana kadar ve devre arasında yayınlanan ve taraftarın dikkatini çeken bir reklam türüdür.

Seyirci Çıkış1 Sabit Pano: Bütün stadyumun görüş açısında olan bir reklam yeridir.

Stadyum Çıkışı Sabit Pano: Bütün stadyumun görüş açısında ve kameraların çekim alanında yer alan etkili bir reklam alanıdır.

Sporcu Çıkışı Sabit Pano: Futbolcular ile idari kadronun sahaya çıkış güzergâhında yer alan bir reklam yeridir.

Tribün Üzeri Led / Sabit Pano: Stadyumdaki seyircilerin görüş açısına sahip, dikkat çekici ve hedef kitleye rahat ulaşan reklam alanıdır.

Basın Odası: Teknik heyetin, oyuncuların ve yöneticilerin maç sonunda ya da kulübün yapacağı tanıtımlar, imza törenleri için toplandıkları basın odasında kullanılan reklam alanlarıdır. 
Mixed Zone: Naklen yayın çekimlerinde de görülebilen sporcuların maç öncesi ve sonrası röportaj verdikleri alanlardır.

Yedek Kulübesi: Stadyumdaki seyircilerin açık bir görüş açısına sahip, futbolcu ve teknik heyetin maç oynanırken kameralar tarafından görüntülendiği reklam alanıdır.

Scoreboard: Maç öncesinde ve devre arasında sesli olarak seyirciye sunulan animasyonlu led reklam alanıdır.

Scooter reklamı; Maç öncesi ve devre arasında, saha kenarında yer alan reklam çalışmasıdır. Maskot reklamı; Maç boyu saha kenarında yer alan reklam çalışmasıdır.

Koltuk Arkası Reklam: Seyirci koltuğunun arkasında yer alan doğrudan seyirciye hitap eden bir reklam çalışmasıdır.

Web Sayfası Reklam / Antrenman Reklam Panoları: Kulüplerin resmi internet sayfalarında yer alan ve her gün binlerce kişiye ulaşan bir reklam çalışmasıdır.

Forma Reklam Çalışması: Takım formasının sadece ön yüzünde, sağ kolunda, arka yüzünde numaranın üst kısmında, şortun sağ ön yüzünde ve konçta bulunan reklam alanıdır.

Event Alanı: Maç öncesi ve maç sonrası seyircilere çeşitli etkinliklerle ürün tanıtımını sağlayan reklam çalışmasıdır.

VIP Loca: Localarda ve koridorlarda VIP seyirciye yönelik özel televizyon ekranlarında yayınlanan reklam çalışmasıdır.

DigiPaint / 3D Halı: Oyun alanı dışında kalan bölgelerde, izleyicinin gerçek bir yüksekliğe sahipmiş gibi algıladığ 1 reklam türüdür.

Spor yerleri reklamları sponsorlara ait olabileceği gibi, sponsor olmayanların reklamları da olabilir. Bu bağlamda sponsorluk gelirleri ile spor yerleri reklam gelirleri çok net çizgileriyle ayrılamayabilir. Spor yerine reklam vermek için sponsor olmak gerekmediği açıktır. Dolayısı ile spor yeri reklamlarını sponsorluk başlığı altında ele alıp değerlendirmek yerine ayrı olarak incelemek daha doğru olacaktır.

\section{g) Viral Reklam}

Viral reklam, "kulaktan kulağa pazarlama"nın internet dünyasına uyarlanmış bir türü diyebiliriz. Viral reklamın temeli yayılmayı kolaylaştırarak, insanların gördüklerini başkalarıyla paylaşmalarını sağlayacak öğeleri yerleştirmektir. (Eser, 2016). Ağızdan ağıza iletişimin daha etkili bir yayılma şekli olduğu düşünüldüğünden, birçok marka artık geleneksel reklam yöntemlerini tercih etmemektedirler. (Tokel, 2017)

Kullandığı bir ürünün ya da bir mağaza açılışına katılan sporcunun sosyal medyada yer alan fotoğraf ya da videolarının beğeni alması viral reklama verilecek örneklerdir. Bu ve benzeri resim ve videolar tesadüfen fazla ilgi toplayıp herhangi bir ürün ya da hizmetin tanıtımına katkı sağlayabilir; ya da bu tamamen kurgulanmışta olabilir. Nitekim "Arabasını Satıp Fenerbahçe'ye 70 Bin TL Bahis Oynayan Adam" diye haber olan ve sosyal medyada geniş yer bulan video kurgulanmış olan başarılı bir viral reklam örneğidir. YouWin kendini böyle tanıtmış oldu. 
Garanti Bankası 2014 FIBA Kadınlar Dünya Şampiyonası'na katılacak bayan basketbol milli takımına maç öncesi moral olması için, Kenan Doğulu'nun “Güzeller İçinden” şarkısından bir marş hazırlatmış, ayrıca sanatçının kılık değiştirmesi ile bayan basketbol milli takımına bir sürpriz yapmıştır. Videoyu 4 milyona yakın kişi izlemiştir. Avustralyalı paraşütçü ve yüksek atlamacı Felix Baumgartner'ın 2012 yılında, Red Bull sponsorluğunda 39 km yükseklikten atlaması ile ilgili videoyu 38 milyon kişi izlenmiştir. Baumgartner'ın atlayışı sırasında üzerinde Red Bull logolu kıyafet ve "Red Bull Kanatlandırır" sloganı bulunuyordu. Kurgulanmış viral reklamın yapısal içeriği şudur. İşletmenin profesyonel olarak çalışan bir firma ile bu işi yapması ama reklamın seyircilere, amatörce çekilmiş olarak görünmesidir.

Viral reklam son zamanlarda her alanda çok yaygın olarak kullanılmaktadır. Viral reklamın çalışma konumuzla ilgili olan kısmı ürün ve hizmetlerini tutundurmak için spor, sporcu ve spor örgütlerinin kullanılması şartı gerçekleşmelidir. Bu durumda spor yoluyla pazarlama arasında viral reklam da yerini alacaktır.

\section{SONUÇ}

Sonuç olarak spor pazarlaması dört boyuta sahiptir. Bu boyutlar Serarslan'ın çalışmalarında (Serarslan, 1990a; Serarslan, 1990b) "sosyal pazarlama açısından spor pazarlanması", "hizmet pazarlaması açısından spor pazarlaması", "sporcu pazarlaması" ve "spor yoluyla pazarlama" olarak sıralanmıştır. Bu çalışmada da "spor yoluyla pazarlama" analitik olarak değerlendirilmiş, kurum, kuruluş ve özel şirketlerin bünyelerindeki kulüpler; sponsorluk, müşteri firmalar arasında düzenlenen spor organizasyonları; reklamlarda ünlü sporcuların değerlendirilmesi, lisanslama; spor yerleri reklamları ve viral reklam, spor yoluyla pazarlama seçenekleri olarak ortaya konulmuştur.

Nitekim spor yoluyla pazarlama; örgütlerin yapılarında spor kulübü kurup dinamik bir biçimde por faaliyetlerinde yer almak; spor olaylarını, spor takımlarını, faaliyetlerini yada sporcuların desteklenmesi (sponsorluğunu yapmak) ve spor yeri (Türk Telekom Arena...), lig (Türksel süper lig...), kulüp (Vestel Manisa...) isim hakları; iş bağlantısı kurmada yardımı bulunacak muhtelif spor organizasyonlarının yapılmalarını temin etmek ve iştirak etmek ; ürün reklamlarında sporculara yer vermek (Opet Arda Turan, THY Kobe ve Messi...); sporcunun kullandığg bir ürünün sosyal medyada beğeni alması ya da "kulaktan kulağa pazarlama'nın internet dünyasına uyarlanmış bir türü denilebilecek viral reklam; Lisanslama (çilek mobilya, taç...) şeklinde gerçekleşebilmektedir.

\section{ÖNERILER}

"Spor yoluyla pazarlama" kavramı ve içeriği ile ilgili daha kapsamlı çalışmalar yapılmalı. Spor pazarlamasının diğer boyutları olan "sosyal pazarlama açısından spor pazarlanması", "hizmet pazarlaması açısından spor pazarlaması" ve "sporcu pazarlaması" kavramlarının da tartışılması ve üzerinde analitik çalışmalar yapılması yararlı olacaktır. Üzerinde analitik çalışmaya ihtiyaç olan diğer bir alan spor ürünü kavramıdır. Başka bir kavramda "spor pazarlama bileşenleri" kavramıdır. Nitekim literatürde endüstri işletmelerinde "4 P" olarak karşımıza çıkan pazarlama bileşenleri ya da karması hizmet işletmelerinde "5 P", "7 P" ya da daha farklı sayılarda karşımıza çıkmaktadır. Bu bağlamda spor pazarlamasında bu durumun tartışılmasına ihtiyaç vardir. 


\section{KAYNAKLAR}

Akkaya, Y. (2016). Sponsorluk faaliyetlerinin spora etkilerinin incelenmesi. International Journal of Science Culture and Sport (IntJSCS), 4(3), 811-820.

Aytaç, K., Yenel İ. (2012). Taraftarların spor kulüplerindeki lisanslı ürün pazarlama faaliyetlerine ilişkin tutulan takım değişkenine göre satın alma tutumlarının incelenmesi. Adıyaman Üniversitesi Sosyal Bilimler Enstitüsü Dergisi, (9), 31-11.

Bir, A.A. (21.05.2006). Ne Ronaldinho imiş ama. Hürriyet Gazetesi,

Ekmekçi, R., Ekmekçi Y.A. (2010). Spor pazarlaması. Pamukkale Journal of Sport Sciences, 1(1), 23-29.

Eser, G., Bilgi Sayamiyorum Web Sitesi: Viral reklam nedir, nasıl yapılır? (http://bilgisayamiyorum.com/post/64/) Erişim: 05.12.2016

Freidon, J. B. (1984). Advertising spokeperson effects: an examination of endorsen type and gender on two audience. Journal of Advertising Research, 24(5), 33-40.

Karasar, N. (2015). Bilimsel araştırma yöntemi. 21. Basım, Nobel Yayın Dağıtım, Ankara.

Lisans A.Ş., Lisans nedir. Licensing and Brand Management, (http://lisansas.com.tr/lisans-nedir/ Erişim tarihi: 07.03.2019).

McCormack, M. H. (2014). What they don't teach you at harvard business school. Profile Books

Moore, T. L. (1985). Business office becomes new playing field. Advertising Age, Chicago, 56(85), 17-18.

Mullin, B. J., Hardy S., Sutton W.A. (2010).Sport marketing. Second Edition, Human Kinetics.USA,

Serarslan, M. Z. (1989). Kurum kulüplerinin kuruluş amaçları ve Türk sporu içindeki yerleri. Spor Bilimi Dergisi, İstanbul, $1,44-61$.

Serarslan, M. Z. (1990a). Spor pazarlaması: Sporun topluma yaygınlaştırılmasında pazarlama tekniklerinden yaralanma. İstanbul Üniversitesi, Sosyal Bilimler Enstitüsü, Basılmamış Doktora Tezi, İstanbul.

Serarslan, M. Z. (1990b). Spor pazarlaması ve boyutları. Spor Bilimleri 1. Ulusal Spor Sempozyumu Bildiriler, Hacettepe Üniversitesi, Ankara, 15-16 Mart, 217-224.

Serarslan, M. Z. (1990c). Spor mantalitesinin geliştirilmesinde pazarlama tekniklerinden yararlanma. Spor Bilim, $1(3-4), 39-41$.

Serarslan, M. Z. (2009). Futbol pazarlaması. Türkiye Futbol Federasyonu FGM Futbol Eğitim Yayınlar1-9, İstanbul,

Sezgin, M., Yılmaz, E. (2019). Televizyon reklamlarında ünlü kullanımının tüketiciler açısından değerlendirilmesi: uşak üniversitesi iletişim fakültesi öğrencilerine yönelik bir araştırma. Karabük Üniversitesi Sosyal Bilimler Enstitüsü Dergisi, 9(2), 472-488.

Stone, G., Joseph, M., Jones, M. (2003). An exploratory study of the sports celebrities in advertising: a content analysis. Sport Marketing Quarterly, 2(12).

Sunay, H., Balcı, V. (2003). Bazı Türk televizyonlarının yayınladığı reklamlarda spor imajının kullanımı. Spormetre Beden Ĕ̈itimi ve Spor Bilimleri Dergisi, 1(2), 107-110.

Tekin, N., Eskicioğlu, Y.E. (2015) Spor sponsorluğu: Türk Hava Yolları - Türkiye Basketbol Federasyonu örneği. Spor Yönetimi ve Bilgi Teknolojileri Dergisi, 10(1), 14-36.

Tokel, A. (2017). Viral reklamların görsel iletişim tasarımıyla ilişkisi. Işık Üniversitesi Sosyal Bilimler Enstitüsü, Basılmamış Yüksek Lisans tezi, İstanbul. 
Tosun, N., Dündar, A. (2019). Marka Tutumu Oluşumunda Ünlü Futbolcuların Televizyon Reklamlarında Kullanımı. Sosyal Bilimler Kongre Kitabi UBAK Uluslararası Bilimler Akademisi. Edirne 5-7 Nisan, 83-103.

Turgut, İ. (1984). Eğitimde felsefenin işlevi (analitik yöntem ve eğitim). Eğitim Bilimleri Sempozyumu, 5-6 Nisan, Ankara.

TMOK. (1991). Sporda marketing semineri. Sporda Marketing Semineri Notları, T.C. Başbakanlık Gençlik ve Spor Genel Müdürlüğü Spor Eğitimi Dairesi Başkanlığı, 8-9 Nisan, İstanbul.

Otker, T., Hays, P. (1987). Judging the efficiency of sponsorship: experience from the 1986 soccer World Cup. ESOMAR Congres Report, 3.

Ülgen, H., Mirze, S. K. (2004). Işsletmelerde stratejik yönetim. 1. Baskı: Literatür Yayınları, İstanbul.

Yaka, A. Analitik yöntem. Toplumsal Dinamik, Sosyolojik Irdelemeler, http://www.aydinyaka.com/index.php/tum-makaleler/27-analitik-yontem.html) Erişim tarihi:22.03.2019.

Yıldız, Y., Çetinöz, F., Kaplan, Y., Türkmen, M. (2007). Tv reklamlarında spor imajının kullanılması ve tüketici davranışları üzerine etkisi. Spor Yönetimi ve Bilgi Teknolojileri Dergisi, 2(1), 5-13.

Zeki, A. (1998). Reklam ve imajları. Bilişim Yayınları, Ankara.

T.C. Resmi Gazete. 2908 Sayılı Dernekler Kanunu. Sayı: 18184 Başbakanlık Basımevi, Ankara, 7 Ekim 1983.

T.C. Resmi Gazete. 5253 Sayılı Dernekler Kanunu. Sayı: 25649 Başbakanlık Basımevi, Ankara, 23 Kasım 2004.

T.C. Resmi Gazete. Gençlik ve Spor Genel Müdürlüğü İşletme Yönetmeliği Sayı:26018, Başbakanlık Basımevi, Ankara, 9 Aralık 2005.

T.C. Resmi Gazete. Gençlik ve Spor Kulüpleri Yönetmeliği Sayı: 18825, 28 Temmuz 1985. 